\title{
Endothelin I levels in relation to clinical presentation and outcome of Henoch Schonlein purpura S Fessatou ${ }^{1}$, P Nicolaidouㄴ, D Gourgiotis ${ }^{2}$, H Georgouli², K Douros ${ }^{1}$, M Moustaki ${ }^{1}$ and A Fretzayas*1,3
}

Address: ${ }^{3}$ rd Department of Pediatrics "Attikon" University Hospital, Athens University School of Medicine, Athens, Greece, 22nd Department of Pediatrics, "P \& A Kyriakou" Children's Hospital Athens University School of Medicine, Athens, Greece and 33rd Department of Pediatrics, University of Athens, Attikon University Hospital, 1 Rimini str, Haidari, 12462, Athens, Greece

Email: S Fessatou - sfessatou@yahoo.gr; P Nicolaidou - pedatt@med.uoa.gr; D Gourgiotis -ppk@otenet.gr; H Georgouli - ppk@otenet.gr; K Douros - costasdouros@gmail.com; M Moustaki - maria-m@otenet.gr; A Fretzayas* - afretz@med.uoa.gr

* Corresponding author

Published: 2 September 2008

BMC Pediatrics 2008, 8:33 doi:10.1 |86/|47|-243|-8-33
Received: 17 April 2008

Accepted: 2 September 2008

This article is available from: http://www.biomedcentral.com/I47I-243I/8/33

(c) 2008 Fessatou et al; licensee BioMed Central Ltd.

This is an Open Access article distributed under the terms of the Creative Commons Attribution License (http://creativecommons.org/licenses/by/2.0), which permits unrestricted use, distribution, and reproduction in any medium, provided the original work is properly cited.

\begin{abstract}
Background: Henoch Schonlein purpura (HSP) is a common vasculitis of small vessels whereas endothelin-I (ET-I) is usually reported elevated in vasculities and systematic inflammation. The aim of the present study was to investigate whether ET-I levels are correlated with the clinical presentation and the outcome of HSP.

Methods: The study sample consisted of thirty consecutive patients with HSP. An equal number of healthy patients of similar age and the same gender were served as controls. The patients' age range was $2-12.6$ years with a mean $\pm \mathrm{SD}=6.3 \pm 3$ years. All patients had a physical examination with a renal, and an overall clinical score. Blood and urinary biochemistry, immunology investigation, a skin biopsy and ET-I measurements in blood and urine samples were made at presentation, I month later and I year after the appearance of HSP. The controls underwent the same investigation with the exception of skin biopsy.
\end{abstract}

Results: ET-I levels in plasma and urine did not differ between patients and controls at three distinct time points. Furthermore the ET-I were not correlated with the clinical score and renal involvement was independent from the ET-I measurements. However, the urinary ET-I levels were a significant predictor of the duration of the acute phase of HSP $(H R=0.98, p=0.032$, CI0.96-0.99). The ET-I levels did not correlate with the duration of renal involvement.

Conclusion: Urinary ET-I levels are a useful marker for the duration of the acute phase of HSP but not for the length of renal involvement.

\section{Background}

Henoch Schonlein purpura (HSP) is a well known systemic small vessel vasculitis characterized by major manifestations; arthritis, nonthrombocytopenic purpura, abdominal pain and renal disease. The latter is of major concern since it may result in lifelong problems. Although the pathogenesis of HSP remains largely unknown there is strong evidence that IgA has a pivotal role given the increased serum IgA concentrations, IgA with concomitant circulating immune complexes and IgA deposition in 
vessel walls and renal mesangium have been observed during the course of the disease. Furthermore, activation of the alternative pathway of complement and cytokine abnormalities has also been implicated as having a role in HSP pathogenesis [1].

Endothelins (ETs) were first found by Yanagisawa et al. in 1988 [2] and 3 isoforms of this peptide, ET-1, ET-2, ET-3, have been isolated [3]. Their biological activities cover a wide spectrum which includes regulation of hormones and neurotransmitter, cellular growth and proliferation, bronchoconstriction, natriuresis and water diuresis (4). Urine contains higher concentrations of ET compared to those of plasma which is mainly derived from the in situ production by the kidneys [4].

Endothelin-1 (ET-1) is a potent vasoconstrictor and its concentrations in plasma are increased markedly in a number of pathologies, such as ischemia induced damage and reperfusion, vasculities of various types, congestive heart failure, systemic inflammatory response seen in septic shock syndrome and similar pathology [5]. In a study by Muslu A et al. it was shown that ET-1 plasma levels were significantly higher in HSP patients during the acute phase compared to levels in remission but also to levels in healthy controls [6].

The purpose of this study was to determine whether ET-1 levels in plasma and urine are related to the severity of the clinical presentation and the outcome of HSP.

\section{Methods}

Thirty patients with HSP were recruited during a 2 year period from January 2005 to December 2006. The control group consisted of an equal number of healthy children matched for age and gender. The age range was 2-12.6 years with a mean of $6.3 \pm 3$ years. The respective ages for the controls were $2-12.7$ years and $6.2 \pm 2.6$ years. Male to female ratio was $14 / 16$ in both groups. Informed consent was obtained from the parents of all participants and the study was approved by the Local Ethics Committee. The diagnosis of HSP was based on the criteria established by the American College of Rheumatology [7]. A punch skin biopsy was performed in all patients in order to verify the diagnosis. Biopsies were obtained from affected and non affected skin within 48 hours of the appearance of the lesions.

A detailed history and a complete physical examination were obtained from all patients. A clinical scoring system adjusted from De Matia D et al. and Muslu A et al. which consisted of the sum of three distinct scores for arthritis, abdominal symptoms and renal involvement were used to assess disease activity and severity $[6,8]$. This score was modified by using more objective criteria (Table 1). Severity of the disease was determined as mild or severe, if the clinical score was $\leq 4$ or $>4$, respectively

Laboratory measurements included complete blood count, erythrocyte sedimentation rate (ESR), $\mathrm{C}$ reactive protein (CRP), total protein and albumin, blood and urine electrolytes, immunoglobulins (IgA, IgG, IgM), C3, C4, ASO, ANA, anti-DNA, Ra test, p-ANCA, blood urea nitrogen (BUN), creatinine, culture of pharyngeal swabbing and stool guiac test and routine urinalysis (which was performed every 15 days during the study period). In a random urine specimen taken at the same time with the creatinine blood sample, ET-1(expressed as creatinine ratio) and N-acetyl-b-D glucosaminidase (NAGexpressed as creatinine ratio), was measured as a sensitive

Table I: The clinical scoring system in patients with $\operatorname{HSP}(6,8)$

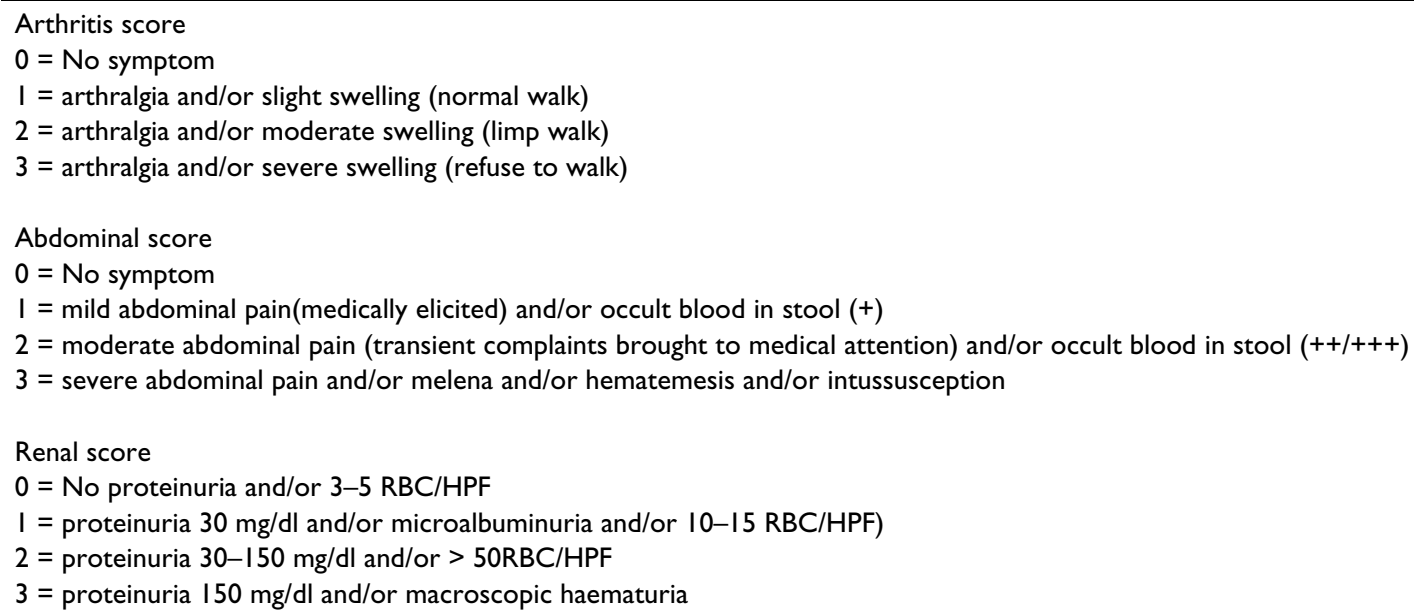

RBC: red blood cells 
marker of tubular damage. Creatinine, total protein and a1 and b2 microglobulin were also calculated in a 24 hours urine collection as tubular markers and microalbumin as a marker of glomerular damage. The children who presented with gross or mild haematuria and/or proteinuria and/or tubular or glomelural involvement were considered as having renal involvement.

Venous blood samples for plasma ET-1 determination were collected in frozen plastic tubes containing EDTA ( $0.1 \mathrm{ml} \mathrm{EDTA} / \mathrm{ml}$ of blood) after $30 \mathrm{~min}$ of supine rest. They were promptly centrifuged and stored in tubes containing aprotinine at $-70^{\circ} \mathrm{C}$ until analyzed. Plasma ET-1 levels were determined by radioimmunoassay (RIA) (Endothelin 1-21 specific [ $\left.{ }^{125} \mathrm{I}\right]$ columns (Amersham Biosciences Amprep $^{\mathrm{TM}} 500 \mathrm{mg}$ C2 columns). The sensitivity of the assay was $1.2 \mathrm{pg} / \mathrm{ml}$. The intra and inter assay variability were $4.8 \%$ and $13.8 \%$ respectively. Urinary NAG levels were measured following a fluorometric method described by Leadback and Walker [9] as well as by Woolen and Walker [10] and subsequently modified by Gnanadurai et al [11]. The urinary creatinine levels were analyzed by Jaffe's method for calculating NAG/creatinine quotients [12].

Patients were examined and underwent all the aforementioned laboratory tests at 3 distinct time points. The first at the time of diagnosis of HSP corresponding to the acute phase. The second, 1 month later or when renal involvement was diagnosed (which ever happened first) and the third 1 year later which roughly corresponded to the remission of the disease. Four patients continued to present with renal impairment even after 15, 24, 14 and 18 months respectively and for that reason their last examination did not correspond to their remission phase.

\section{Statistical methods}

Continuous variables are expressed as mean \pm SD whereas time variables as median (p50), 25 th percentile (p25) and $75^{\text {th }}$ percentile $(\mathrm{p} 75)$. In univariate analysis we compared means between different groups with t-test and one way Anova and we used Spearman's rho to search for any correlations between variables. In multivariate analysis, we used logistic regression to see if ET-1 was a predictive factor for renal damage and Cox Proportional Hazard models which were used to estimate relative risk [expressed as hazard Ratio (HR)] of remission associated with a unit change in a covariate, to explore for any correlations between ET-1 and the length of the disease. We used the backward procedure for selecting the best models. The statistical significance threshold was set at $\mathrm{p}<0.05$.

\section{Results}

Twenty-three $(76.6 \%)$ of our patients had mild and 7 $(23.4 \%)$ had severe disease. Rash was evident in all patients at presentation. In $12(40 \%)$ of them it was preceded by: arthritis, in $6(20 \%)$ by gastrointestinal complaints, in $5(17 \%)$ hematuria in 1 (3\%). Histological examination of the skin biopsies revealed typical leukocytoclastic vasculitis in all patients; whereas immunofluorescence studies showed perivascular IgA deposition in 28 (93.3\%), C3 deposition in 13(43.3\%) and IgM deposition in $5(16.6 \%)$ patients.

During the course of the disease, arthritis occurred in 25 $(83 \%)$, gastrointestinal involvement in $24(80 \%)$ and renal involvement in $18(60 \%)$ patients. Blood pressure was within normal limits in all patients apart from 1 who developed nephritic syndrome.

Only one patient who finally developed nephrotic syndrome, had low total protein and albumin. Four more patients had proteinuria, which was not at nephrotic levels and 10 microalbuminuria. Levels of NAG, a-1 and b-2 microglobulin were within normal limits in all patients. The clinical hallmark of HSP nephritis is haematuria. In our study $12 / 30(40 \%)$ patients had microscopic and 5/ $30(16.6 \%)$ developed gross haematuria. Four patients of the latter group finally developed proteinuria and two of them underwent renal biopsy which revealed glomerulonephritis characterized by diffuse hypercellularity and mesangial proliferation.

Laboratory assays taken at presentation, were within normal limits with the exception of raised IgA in $14 / 30$ (46\%), elevated $\mathrm{C}_{3}$ values in $1 / 30$ (3.3\%) (Table 2), and high ASO titers (> $200 \mathrm{IU} / \mathrm{ml}$ ) in 17/30 (56\%). The culture of pharyngeal swabbing was positive for group A beta hemolytic streptococcus in 11/30 (36\%).

Positive stool guiac test was detected in 16 (53.3\%), haematemesis in $2(6.6 \%)$, melena in 4 (13.3\%) and intussusception in 1 patient. The duration of time variables expressed as median (P50) and $25^{\text {th }}$ and $75^{\text {th }}$ percentile (p75, p25) in days were $8(14,5)$ for the acute phase of the disease, $45(362,5)$ for microhaematuria and $34(92,5)$ for microalbuminuria.

No differences were found in ET-1 levels in plasma and urine between patient and control groups at each of the three distinct time points (Table 3 ). Also there was no correlation between renal or overall clinical score and ET-1 values in plasma and urine on the 3 time points (Table 4, $5)$ between patients with and without renal involvement (Table 6).

Of note, in order to investigate if any correlation existed between ET-1 in acute phase and renal involvement, we used two logistic regression models (one for ET-1 in plasma and one for ET-1 in urine) and in each one we 
Table 2: Clinical score and selected laboratory values in patients with HSP, at presentation (IgA, $\left.C_{3}\right)$ and at three distinct time points (ET-I).

\begin{tabular}{|c|c|c|c|c|c|c|c|c|c|c|}
\hline \multirow[b]{2}{*}{ Patient No } & \multirow[b]{2}{*}{$\begin{array}{l}\text { Age (years) } \\
\text { /Gender } \\
\text { (M/F) }\end{array}$} & \multirow[b]{2}{*}{$\begin{array}{l}\lg A \\
(\mathrm{mg} / \mathrm{dl})\end{array}$} & \multirow[b]{2}{*}{$\begin{array}{l}\mathrm{C} 3 \\
(\mathrm{mg} / \mathrm{dl})\end{array}$} & \multirow[b]{2}{*}{$\begin{array}{l}\text { Clinical } \\
\text { score }\end{array}$} & \multicolumn{2}{|c|}{ | st time point } & \multicolumn{2}{|c|}{$2^{\text {nd }}$ time point } & \multicolumn{2}{|c|}{$3^{\text {rd }}$ time point } \\
\hline & & & & & $\begin{array}{l}\text { ET-I } \\
\text { in plasma } \\
(\mathrm{pg} / \mathrm{ml})\end{array}$ & $\begin{array}{l}\text { ET-I } \\
\text { in urine } \\
(\mathrm{pg} / \mathrm{ml})\end{array}$ & $\begin{array}{l}\text { ET-I } \\
\text { in plasma } \\
(\mathrm{pg} / \mathrm{ml})\end{array}$ & $\begin{array}{l}\text { ET-I } \\
\text { in urine } \\
(\mathrm{pg} / \mathrm{ml})\end{array}$ & $\begin{array}{l}\text { ET-I } \\
\text { in plasma } \\
(\mathrm{pg} / \mathrm{ml})\end{array}$ & $\begin{array}{l}\text { ET-I } \\
\text { in urine } \\
(\mathrm{pg} / \mathrm{ml})\end{array}$ \\
\hline 1 & $5 . / F$ & 261 & 204 & 2 & 15.388 & 9.147 & 16.2 & 40.112 & 16.57 & 39.742 \\
\hline 2 & $9.5 / \mathrm{F}$ & 162 & $|4|$ & 1 & 17.568 & 22.843 & 16.75 & 60.149 & 16.78 & 56.631 \\
\hline 3 & $10 / F$ & 802 & 139 & 2 & 9.96 & 75.957 & 21.55 & 24.874 & 15.64 & 39.401 \\
\hline 4 & $2 / M$ & 101 & 116 & 3 & 13.519 & 55.413 & 16.64 & 25.85 & 15.89 & 38.46 \\
\hline 5 & $2 / M$ & 107 & 118 & I & 9.158 & 53.148 & 14.56 & 23.69 & 15.6 & 37.75 \\
\hline 6 & $11.5 / \mathrm{M}$ & 278 & 128 & 3 & 15.637 & 23.54 & 16.63 & 30.71 & 16.97 & 25.589 \\
\hline 7 & $10.5 / F$ & 254 & $|4|$ & 3 & 8.099 & 21.07 & 14.26 & 85.07 & 15.97 & 61.322 \\
\hline 8 & $4 / F$ & 171 & 108 & 4 & 14.329 & 34.932 & 17.5 & 27.258 & 15.72 & 45.46 \\
\hline 9 & $5.5 / \mathrm{M}$ & 323 & 121 & 6 & 18.316 & 43.31 & 16.69 & 52.272 & 16.47 & 48.37 \\
\hline 10 & $5.5 / \mathrm{M}$ & 261 & 116 & 7 & 15.45 & 40.02 & 11.4 & 30.616 & 11.08 & 11.505 \\
\hline 11 & $12.5 / \mathrm{M}$ & 223 & 172 & 5 & 8.659 & 12.346 & 10.65 & 20.706 & 19.17 & 113.235 \\
\hline 12 & $2 / \mathrm{F}$ & 81.7 & 147 & 2 & 14.515 & 35.614 & 15.26 & 42.23 & 15.97 & 38.46 \\
\hline 13 & $\mathrm{II} / \mathrm{M}$ & 218 & 148 & I & 16.69 & 31.3 & 14.39 & 22.357 & 15.9 & 34.093 \\
\hline 14 & $3.5 / F$ & 112 & 127 & I & 16.63 & 34.646 & 19.62 & 42.578 & 23.5 & 41.68 \\
\hline 15 & $3.5 / \mathrm{F}$ & 210 & 104 & I & 12.46 & 16.329 & 17.75 & 73.666 & 16.26 & 45.03 \\
\hline 16 & $8 / \mathrm{F}$ & 288 & 137 & 2 & 14.57 & 48.38 & 17.38 & 45.133 & 16.34 & 44.627 \\
\hline 17 & $8 / M$ & 204 & 151 & 2 & 15.64 & 23.78 & 17.88 & 28.657 & 15.98 & 36.95 \\
\hline 18 & $8 / F$ & 402 & 116 & 3 & 26.53 & 32.51 & 18.25 & 86.823 & 17.62 & 89.72 \\
\hline 19 & $5 . .5 / \mathrm{F}$ & 133 & 152 & 3 & 17.13 & 25.918 & 14.82 & 30.406 & 14.98 & 42.78 \\
\hline 20 & $2 / M$ & 129 & 119 & 5 & 13.7 & 22.774 & 17.88 & 52.463 & 23.45 & 30.821 \\
\hline 21 & $7 / F$ & 239 & 164 & 4 & 16.19 & 43.74 & 17.38 & 38.13 & 7.78 & 97.409 \\
\hline 22 & $8.5 / \mathrm{M}$ & 143 & 143 & 2 & 16.57 & 20.225 & 16.01 & 37.31 & 15.79 & 44.63 \\
\hline 23 & $7.5 / \mathrm{M}$ & 156 & 106 & 8 & 11.21 & 23.737 & 18 & 63.22 & 23.31 & 95.465 \\
\hline 24 & $4 / F$ & 193 & $14 \mid$ & 3 & 18.87 & $|6.73|$ & 8.72 & 23.641 & 15.34 & 38.538 \\
\hline 25 & $4 / M$ & 377 & 117 & 4 & 18.87 & 33.195 & 22.75 & 58.51 & 19.41 & 44.75 \\
\hline 26 & $5 / M$ & 179 & 147 & 3 & 18.06 & 48.372 & 13.39 & 28.513 & 8.16 & 28.113 \\
\hline 27 & $7.5 / F$ & 174 & 139 & 3 & 26.8 & 20.227 & 21.5 & 59.855 & 15.5 & 19.893 \\
\hline 28 & $6.5 / M$ & 284 & 147 & 5 & 19.49 & 31.143 & 11.21 & 51.412 & 10.77 & 31.48 \\
\hline 29 & $4 / \mathrm{F}$ & 114 & 96 & 1 & 12.27 & 181.192 & 16.82 & 25.594 & 17.55 & 37.985 \\
\hline 30 & $3.5 / F$ & 197 & 130 & 7 & 17.56 & 41.909 & 11.58 & 28.575 & 14.84 & 48.859 \\
\hline
\end{tabular}

$\begin{array}{ll}m & \text { Normal values of } \mathrm{lgA}(\mathrm{mg} / \mathrm{dl}) \\ \dot{\infty} & 4-6 \text { months } 4.4-84\end{array}$

$\infty \begin{array}{ll}7-12 \text { months } 11-106 \\ 0^{-} & 1-5 \text { years } 14-159\end{array}$

ㄱ. 6-10 years 33-236

S Adults 70-312

Normal values of $\mathrm{C}_{3}(\mathrm{mg} / \mathrm{dl})$

I-3 months 53-31

3-12 months 62-180

Adult $83-177$ 
Table 3: ET-I plasma and urine levels at 3 selected time points in HSP patients and controls

\begin{tabular}{lllll}
\hline & & ET-I in patients (mean \pm SD) $)$ & ET-I in controls (mean \pm SD) & \\
\hline I $^{\text {st }}$ measurement & Plasma & $15.66 \pm 4.30$ & $16.75 \pm 5.96$ & 0.41 \\
& Urine & $37.44 \pm 30.78$ & $45.31 \pm 20.33$ & 0.24 \\
$2^{\text {nd }}$ measurement & Plasma & $16.11 \pm 3.26$ & $16.75 \pm 5.96$ & 0.60 \\
& Urine & $42.01 \pm 18.64$ & $45.31 \pm 20.33$ & 0.51 \\
$3^{\text {rd }}$ measurement & Plasma & $16.14 \pm 3.60$ & $16.75 \pm 5.96$ & 0.63 \\
& Urine & $46.95 \pm 23.15$ & $45.31 \pm 20.33$ & 0.77 \\
\hline
\end{tabular}

adjusted for potential confounders namely, age, gender and clinical and laboratory parameters that were measured during the acute phase of the disease i.e. clinical score, ESR, CRP, IgA and C3. Our results show that renal involvement and ET-1 were not correlated $(\mathrm{OR}=1.05$, $95 \%$ CI 0.79-1.383, $\mathrm{p}=0.74$ and $\mathrm{OR}=0.9995 \% \mathrm{CI} 0.95-$ $1.03, \mathrm{p}=0.71$ for ET-1 in plasma and urine respectively).

Using Cox Proportional Hazards models and controlling for the same potential confounders as above, we tried to investigate whether ET-1 was correlated with the length of the acute phase of the disease. We found that there was no significant correlation with ET-1 in plasma but ET-1 in urine was a significant predictor for the length of the acute phase $(\mathrm{HR}=1.01, \mathrm{p}=0.79,95 \% \mathrm{CI} 0.91-1.11$ and $\mathrm{HR}=$ $0.98, \mathrm{p}=0.032,95 \%$ CI 0.96-0.99 for ET- 1 in plasma and urine respectively). The latter result implies that the higher the levels of ET-1 in urine, the longer the acute phase. A more precise expression of the latter result is that for one unit increase in ET-1 in urine, the mean rate of remission of acute phase (instantaneous remission rate) is reduced about $2 \%$.

We also investigated the relation between ET-1 levels during the acute phase and the length of microhaematuria and microalbuminuria adjusting for the same potential confounders as before. We found that ET-1 in plasma and urine did not correlate with renal involvement although ET-1 in plasma showed a trend toward a significant correlation with the duration of microhaematuria (H.R. $=1.51$, $\mathrm{p}=0.055,95 \%$ CI $0.99-2.34$ ).

\section{Discussion}

HSP is the most common vasculitis in childhood. It is a multisystem disease most commonly affecting skin, joints, gastrointestinal tract and kidneys although other organs may also be affected [13]. Its pathogenesis remains largely unknown. However, it is generally considered to be an immune complex-mediated disease characterized by the presence of polymeric IgA1 containing immune complexes which are mainly found in dermal, gastrointestinal and glomerular capillaries [14]. IgA aggregates or IgA complexes with complement deposits in target organs, result in elaboration of inflammatory mediators, including vascular prostaglandins such as prostacyclins which are thought to play a role in the pathogenesis of HSP vasculitis [15].

Alterations in the production of interleukins and growth factors may also have a role in the pathogenesis of HSP. Tumor necrosis factor (TNF), interleukin 1(IL-1) and interleukin-6 (IL-6) may mediate the inflammatory process present in HSP $[1,16,17]$. There is only one study which demonstrated that plasma ET-1 levels in the acute phase were significantly higher compared to the remission phase and to the controls. However plasma ET-1 levels did not correlate with the clinical and laboratory findings with the exception of a minority of patients with severe disease [6]. In our study we did not find any differences of plasma and urine ET-1 levels between patients and controls.

Table 4: ET-I values in plasma and urine at three distinct measurements in relation to renal score

\begin{tabular}{|c|c|c|c|c|c|}
\hline & & ET-I (mean \pm SD, range) & Renal score (Mean $\pm S D$, range) & rho & $\mathrm{P}$ \\
\hline \multirow[t]{2}{*}{ Ist measurement } & Plasma & $16.20 \pm 5.18,2.18-26.80$ & $0.70 \pm 0.91,0-3$ & -0.011 & 0.95 \\
\hline & Urine & $41.38 \pm 26.17,9.14-181.19$ & & 0.099 & 0.59 \\
\hline \multirow[t]{2}{*}{$2^{\text {nd }}$ measurement } & Plasma & $16.11 \pm 3.26,8.72-22.75$ & $0.73 \pm 1.08,0-3$ & -0.180 & 0.92 \\
\hline & Urine & $42.01 \pm 18.64,20.70-86.82$ & & 0.248 & 0.57 \\
\hline \multirow[t]{2}{*}{$3^{\text {rd }}$ measurement } & Plasma & $16.14 \pm 3.60,7.78-23.5$ & $0.1 \pm 0.30,0-1$ & -0.288 & 0.52 \\
\hline & Urine & $46.95 \pm 23.15,11.50-113.23$ & & 0.473 & 0.66 \\
\hline
\end{tabular}

Results from univariate analysis (rho = spearman's correlation coefficient) 
Table 5: ET-I values in plasma and urine at three distinct time point measurements in relation to clinical score.

\begin{tabular}{|c|c|c|c|c|c|}
\hline & & ET-I (mean \pm SD, range) & Clinical score (mean $\pm S D$, range) & rho & $\mathrm{P}$ \\
\hline \multirow[t]{2}{*}{ Ist measurement } & Plasma & $16.20 \pm 5.18,2.18-26.80$ & $3.23 \pm 1.94,1-8$ & 0.145 & 0.443 \\
\hline & Urine & $41.38 \pm 26.17,9.14-181.19$ & & -0.032 & 0.864 \\
\hline \multirow[t]{2}{*}{$2^{\text {nd }}$ measurement } & Plasma & $\mid 6.11 \pm 3.26,8.72-22.75$ & $0.73 \pm 1.08,0-3$ & -0.018 & 0.923 \\
\hline & Urine & $42.01 \pm 18.64,20.70-86.82$ & & -0.106 & 0.576 \\
\hline \multirow{2}{*}{$3^{\text {rd }}$ measurement } & Plasma & $16.14 \pm 3.60,7.78-23.5$ & $0.13 \pm 0.34,0-1$ & 0.011 & 0.952 \\
\hline & Urine & $46.95 \pm 23.15,11.50-113.23$ & & 0.237 & 0.205 \\
\hline
\end{tabular}

Results from univariate analysis (rho $=$ spearman's correlation coefficient).

ET was initially described as a peptide released from large vessel endothelial cells [2]. However other sites of synthesis have subsequently been discovered. ET is also expressed in brain, lung, heart and kidney. As far as the latter location is concerned endothelial, glomerular, tubular epithelial and mesangial cells of the kidney can all synthesize ET [18].

The circulating half life of ET is short (2-3 min) and it is almost completely metabolized in the pulmonary capillaries by the enzyme neutral endopeptidase. A small amount of circulating ET is cleared in the urine [19]. Depending on the nature and the magnitude of the stimulus circulating ET may be elevated in different pathophysiological or experimental conditions. However it is not clear whether an elevated level of circulating ET is necessary for its actions [20]. The effects of ET are detected long after the normalization of the plasma level. These data suggest that the concentration of plasma ET does not correlate with its activity in different cells and tissues and the circulating levels depend on the balance of the luminal endothelial synthesis and metabolism [4].

The kidney and particularly the renal medulla expresses the highest concentration of ET-1 receptors of any organ and also synthesizes ET-1 [21]. Glomerular epithelial and mesangial cells, renal tubular cells and medullary collecting duct cells synthesize and release ET-1. ET-1 is a major mediator of renal vascular tone, tubular secretion of electrolytes and water and vascular smooth muscle and mesangial cell proliferation [22]. ET-1 maintains normal kidney perfusion by increasing renal blood flow, effecting on natriuresis and diuresis [23].

Despite the higher concentration of ET in urine compared to plasma, the urinary excretion of ET does not correlate with the glomerular filtration rate filtered load or plasma levels [24]. It has been suggested that the filtered ET is subject to proteolytic degradation by neutral endopeptidase across the brush border of the proximal tubuli [19]. ET can be a marker of renal injury in different pathological processes in children and in adults but its specificity is low. Therefore ET should be used with caution as a marker of distal tubular or collecting duct epithelial function [4]. $\mathrm{ET} /$ creatinine ratio in random urine samples could be used as a reliable index of urinary excretion of ET $[25,26]$. In our study this urinary ET- 1 was correlated with the duration of the acute phase of the disease.

Several systemic rheumatic diseases in which vascular pathology is related to endothelial cell activation appear to be causally related to endothelin.

They include systemic sclerosis, systemic lupus erythematosus, Takayasu and giant cell arteritis, Raynaud's phenomenon, mixed cryoglobulinaemia, aortoarteritis and Buerger's, Bechcet, Kawasaki, mixed connective tissue and Chaga's disease [27-38]. All these studies measured only plasma ET-1 levels in contrast to our study which measured plasma and urine ET-1 levels (although no differences between patients and controls were found).

Table 6: ET-I values in plasma and urine between patients with and without renal involvement (RI).

\begin{tabular}{lllll}
\hline & & Patients with RI & Patients without RI & $P$ \\
\hline \multirow{2}{*}{ Ist measurement } & Plasma & $15.77 \pm 4.48,8.6-26.8$ & $15.56 \pm 4.29,8.09-26.53$ & $0.85 I$ \\
& Urine & $35.59 \pm 16.80,12.34-75.95$ & $39.06 \pm 39.77,9.147-181.19$ & 0.506 \\
$2^{\text {2d }}$ measurement & Plasma & $16.11 \pm 3.26,8.72-22.75$ & $16.20 \pm 3.25,8.72-22.75$ & 0.891 \\
\multirow{2}{*}{$3^{\text {rd }}$ measurement } & Urine & $38.40 \pm 14.64,20.70-63.22$ & $44.41 \pm 20.94,23.64-86.823$ & 0.582 \\
& Plasma & $16.86 \pm 4.61,11.08-23.31$ & $16.00 \pm 3.47,7.78-23.5$ & 0.977 \\
& Urine & $60.63 \pm 42.53,11.50-113.23$ & $44.22 \pm 17.30,19.89-97.40$ & 0.486 \\
\hline
\end{tabular}




\section{Conclusion}

In conclusion, plasma ET-1 levels cannot be utilized as a predictor of HSP duration or severity whereas urine ET-1 levels are correlated with the duration of the acute phase of the disease.

\section{Competing interests}

The authors declare that they have no competing interests.

\section{Authors' contributions}

SF and PN had substantial contributions to conception and design and analysis and interpretation of data and drafting of the manuscript. DG and HG made all the necessary biochemical measurements $\mathrm{MM}$ and $\mathrm{AF}$ have been involved in drafting and revising the manuscript. KD performed the statistical analysis of the data

\section{References}

I. Scheinfeld SN, Jones LE: Henoch-Schonlein purpura from Pediatrics. EMedicine Journal 2003, 4(6):

2. Yanagisawa M, Kurihara H, Kimura S, Tomobe $Y$, Kobayshi M, Mitsui Y, Yazaki Y, Goto K, Masaki T: A novel potent vasoconstrictor peptide produced by vascular endothelial cells. Nature 1988, 332:4I I-4I5.

3. Inoue A, Yanagisawa M, Kimura S, Kasuya Y, Miyauchi T, Goto K, Masaky $T$ : The human endothelin family: three structurally and pharmacologically distinct isopeptides predicted by three separate genes. Proc Natl Acad Sci USE 1989, 86:2863-2867.

4. Mattyus I, Zimmerhackl LB, Schwarz A, Brandis M, Miltenyi M, Tulassay T: Renal excretion of endothelin in children. Pediatr Nephrol I997, I I(4):5 I3-2I.

5. Warner TD, Klemm P: What turns on the endothelins? Inflamm Res 1996, 45(2):5।-3.

6. Muslu A, Islek I, Gok F, Aliyazicioglu Y, Dagdemir A, Dundaroz R, Kucukoduk S, Sakarcan A: Endothelin levels in Henoch-Schonlein purpura. Pediatr Nephrol 2002, I 7:920-925.

7. Millis JA, Michel BA, Bloch DA, Calabrese LH, Hunder GG, Arend WP, Edworthy SM, Fauci AS, Leavitt RY, Lie JT: The American College of Rheumatology 1990 criteria for the classification of Henoch-Schonlein purpura. Arthritis Rheum 1990, 33: I I I4- I I 2 I.

8. De Mattia D, Penza R, Giordano P, Del Vecchio GC, Aceto G, Altomare M, Schettini F: Von Willebrand factor and factor XIII in children with Henoch-Schonlein purpura. Pediatr Nephrol 1995, 9:603-605.

9. Leaback DH, Walker PG: The Fluorimetric Assay of N-Acety-Bglucosaminidase. Biochem J 1961, 78:151-156.

10. Woollen JW, Walker PG: The fluorimetric estimation of betaglucuronidase in blood plasma. Clin Chim Acta 1965, I 2(6):659-70.

II. Gnanadurai TV, Brantheaite MA, Colbeck JF, Welman E: Lysosomal enzyme release during cardiopulmonary bypass. Anaesthesia 1997, 32(8):743-8.

12. Forbes GB, Bruining GJ: Urinary creatinine excretion and lean body mass. Am J Clin Nutr 1976, 29( I 2): I 359-66.

13. Tizard EJ: Henoch-Schonlein purpura. Arch Dis Child 1999, 80:380-383.

14. Rai A, Nast C, Adler S: Henoch-Schonlein nephritis. J Am Soc Nephr 1999, I0( I 2):2637-44.

15. Turi S, Belch JJF, Beattie TJ, Forbes CD: Abnormalities of vascular prostaglandins in Henoch-Schonlein purpura. Arch Dis Child 1986, 61:173-177.

16. Rostoker G, Rymer JC, Bagnard G, Petit-Phar M, Griuncelli M, Pilatte $Y$ : Imbalances in serum proinflammatory cytokines and their soluble receptors: a putative role in the progression of idiopathic IgA nephropathy (IgAN) and Henoch-Schonlein purpura nephritis, and a potential target of immunoglobulin therapy? Clin Exp Immunol I 998, I I 4(3):468-476.

17. Wu TH, Wu SC, Huang TP, Yu CL, Tsai CY: Increased excretion of tumor necrosis factor alpha and interleukin I beta in urine from patients with IgA nephropathy and Henoch-Schonlein purpura. Nephron 1996, 74(I):79-88.

18. Kon V, Badr KF: Biological actions and pathophysiologic significance of endothelin in the kidney- editorial review. Kidney Int 1991, 40:1-12.

19. Abassi ZA, Tate J, Golomb E, Keiser HR: Role of neutral endopeptidase in the metabolism of endothelin. Hypertension 1992, 20:89-95

20. Wagner OF, Christ G, Wojta J, Vierhapper H, Parzer S, Nowotny PF, Schneider B, Waldhaus W, Binder BR: Polar secretion of endothelin-I by cultured cells. J Biol Chem 1992, 267: I6066-I6068.

21. Kuc R, Davenport : Comparison of endothelin-A and endothelin-B receptor distribution visualized by radioligand binding versus immunocytochemical localization using subtype selective antisera. J Cardiovasc Pharmacol 2004, 44(suppl I):S224-S226.

22. Amiri F, Virdis A, Neves MF, Iglarz M, Seidan NG, Touyz RM, Reudelhuber TL, Schiffrin EL: Endothelium-restricted over-expression of human endothelin-I causes vascular remodeling and endothelial dysfunction. Circulation 2004, I 1 0:2233-2240.

23. Villar C, Alonso CJG, Feldstein CA, Juncos LA, Romero JC: Role of endothelin in the pathogenesis of hypertension. Mayo Clinic Proc 2005, 80:84-96.

24. Ohta K, Hirato Y, Shichiri M, Kanno K, Emori T, Tomita K, Marumo $F$ : Urinary excretion of endothelin- $I$ in normal subjects and patients with renal disease. Kidney Int I991, 39:307-3 I I.

25. Tsau YK, Tsai WS, Chen CH: Urinary endothelin-I in children with acute renal failure of tubular origin. J Formos Med Assoc 1998, 97:387-39|.

26. Nicolaidou P, Georgouli H, Getsi V, Tsapra H, Psychou F, Matsinos YG, Zeis PM, Gourgiotis D: Urinary excretion of endothelin-I in children with absorptive idiopathic hypercalciuria. Pediatr Nephrol 2003, I 8: I I57-I I60.

27. Kadono T, Kikuchi K, Sato S, Soma Y, Tamaki K, Takehara K: Elevated plasma endothelin levels in systemic sclerosis. Arch Dermatol Res 1995, 287:439-42.

28. Ferri C, Latorraca A, Catapano G, Greco F, Mazzoni A, Clerico A Pedrinelli R: Increased plasma endothelin-I immunoreactive levels in vasculitis: a clue to the use of endothelin-I as a marker of vascular damage? J Hypertens Suppl 1993, I I(5):SI 42-SI43.

29. Kano K, Hirata Y, Numano F, Emori T, Ohta K, Shichiri M, Marumo F: Endothelin-I and vasculitis [letter]. JAMA I990, 264:2868.

30. Akazawa H, Ikeda U, Kuroda T, Shimada K: Plasma endothelin-I levels in Takayasu artiriris. Cardiology 1996, 87(4):303-305.

31. Uslu T, Erem C, Tosum M, Deger O: Plasma endothelin-I levels in Behçet's disease. Clin Rheumatol 1997, I 6(1):59-6I.

32. Morise T, Takeuchi Y, Takeda R, Karayalcin U, Yachie A, Miyawaki T: Increased plasma endothelin levels in Kawasaki disease: a possible marker for Kawasaki disease. Angiology 1993, 44(9):719-23.

33. Filep JG, Bodolay E, Sipka S, Gyimesi E, Csipö I, Szegedi G: Plasma endothelin correlates with antiendothelial antibodies in patients with mixed connective tissue disease. Circulation 1995, 92:2969-2974.

34. Silveri F, De Angelis R, Poggi A, Muti S, Bonapace G, Argentati F, Cervini $C$ : Relative roles of endothelial cell damage and platelet activation in primary Raynaud's phenomenon (PR) and PR secondary to systemic sclerosis. Scand J Reumatol 200I, 30(5):290-6.

35. Cacoub P, Piette JC, Wechsler B, Bletry O, Godeau P, Carayon A, Maistre G, Legrand JC: Plasma endothelin-I concentrations in polyarteritis nodossa. Ann Rheum Dis 1992, 5 I (5):704.

36. Dang A, Wang B, Li W, Zhang P, Liu G, Zheng D, Ruan Y, Liu L: Plasma endothelin-I levels and circulating endothelial cells in patients with aortoarteritis. Hypertens Res 2000, 23(5):54I-4.

37. Pache M, Kaiser HJ, Haufschild T, Lubeck P, Flammer J: Increased endothelin-I plasma levels in giant cell arteritis: a report on four patients. Am J Ophthalmol 2002, I33(I): 160-2.

38. Petkova SB, Huang H, Factor SM, Pestell RG, Bouzahzah B, Jelicks LA, Weiss LM, Douglas SA, Wittner M, Tanowitz HB: The role of endothelin in the pathogenesis of Chagas' disease. Int J Parasitol 200 I, 3 I(5-6):499-5 II. 


\section{Pre-publication history}

The pre-publication history for this paper can be accessed here:

http://www.biomedcentral.com/1471-2431/8/33/prepub

Publish with Bio Med Central and every scientist can read your work free of charge

"BioMed Central will be the most significant development for disseminating the results of biomedical research in our lifetime. " Sir Paul Nurse, Cancer Research UK

Your research papers will be:

- available free of charge to the entire biomedical community

- peer reviewed and published immediately upon acceptance

- cited in PubMed and archived on PubMed Central

- yours - you keep the copyright 